\title{
Stabilization of the process of mechanized pulsed-arc welding
}

\author{
Sergey Maksimov ${ }^{1}$, Anatoly Gavrilyuk², Denys Krazhanovskyij \\ E.O. Paton Electric Welding Institute \\ Kazimira Malevicha str. 11, Kyiv, Ukraine, 03150 \\ 1 maksimov@paton.kiev.ua, orcid.org/0000-0002-5788-0753 \\ 2 anatolygavrilyuk@ukr.net, orcid.org/0000-0001-5443-6553 \\ 3 kdn17@ukr.net, orcid.org/0000-0001-7292-7188
}

\section{Received 15.07.2020, accepted for publication 23.09.2020 https://doi.org/10.32347/tit2021.42.0202}

\begin{abstract}
The main disadvantage of the mechanized arc welding process in shielding gases with short circuits is the spatter during melting of the electrode metal and its transfer to the weld pool, which affects the productivity of the process, reducing it. Its elimination is possible through the implementation of the controlled transfer of molten electrode metal into the weld pool. The implementation of such a transfer and the control of the processes that take place in the arc gap to a large extent determine the conditions for the qualitative formation of the deposited metal, the stability of the process, the magnitude of the loss of electrode metal and the manufacturability of the processes of arc welding in shielding gases. At the present stage of development of welding technologies, controlled transfer of electrode metal is possible due to the pulsed nature of arc burning. In this case, one of the main methods for increasing the efficiency of the process is to limit the maximum value of the short circuit current by increasing the inductive resistance of the welding circuit.

The research aimed to determine the effect of the rate of rising of the welding current during a short circuit on the stability of the welding arc. It was found that an increase in the current growth rate, starting from $1.23 \mathrm{kA} / \mathrm{s}$ to $50 \mathrm{kA} / \mathrm{s}$, leads to a decrease in the average duration of short circuits by at least 10 times. At the same time, the average frequency of short circuits increases by more than 2 times, from $36 \ldots 38 \mathrm{~s}^{-1}$ to $80 \ldots 86 \mathrm{~s}^{-1}$. The reason for this is the increase in the values of the electrodynamics' Lorentz force, the action of which leads to the compression of the liquid metal bridge of the drop (pinch effect) due to an increase in the short
\end{abstract}

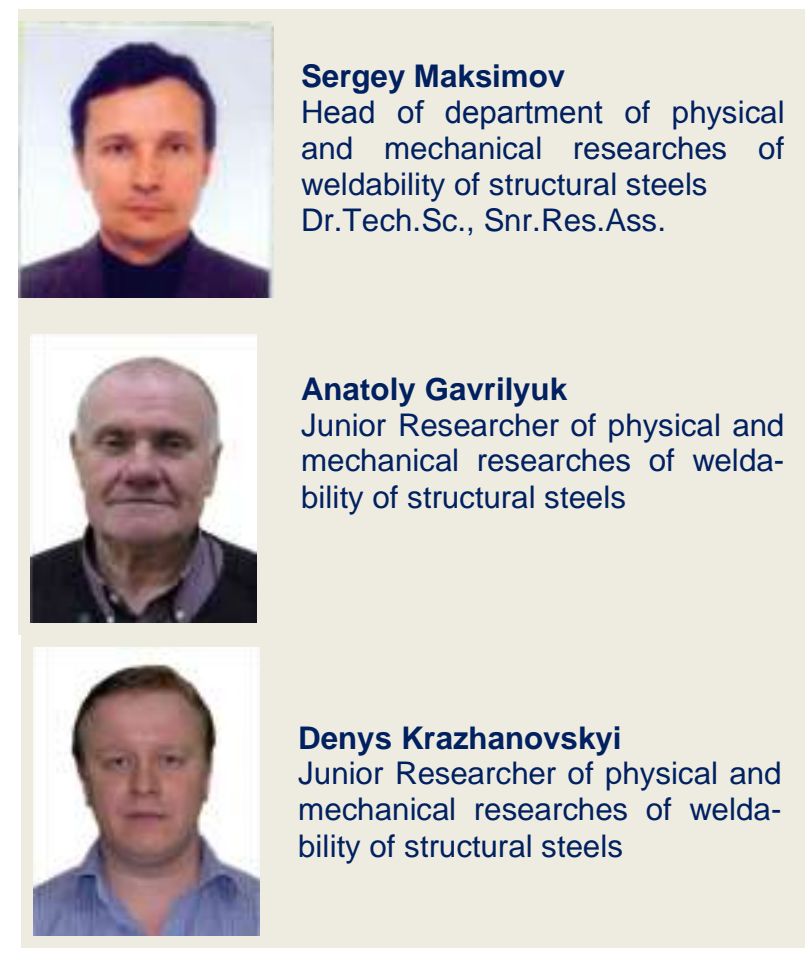

circuit current. At the same time, there is a violation of the stability of the pulse process, and this is reflected in an increase in the average frequency of arc breaks by more than 30 times from $0.33 \mathrm{~s}^{-1}$ to $10 \mathrm{~s}^{-1}$. An increase in the energy parameters of the welding process led to a decrease in the average frequency of short circuits (2...3 times) and their average duration (2 times). The reason for this should be considered a change in the type of transfer of liquid metal - the welding process with short circuits has turned into a mixed process in which, along with short circuits, a droplet transfer of electrode metal is observed. 
Keywords: mechanized arc welding in shielding gases, arc stability, controlled transfer, current source, inductive resistance, short-circuit current rise rate.

\section{INTRODUCTION}

It is known that mechanized arc welding in shielding gases with short circuits (s.c.) is performed at moderate values of the welding current (up to $180 \ldots 220 \mathrm{~A}$ ) and a relatively low voltage $(18 \ldots 24 \mathrm{~V})$ on the arc. The main disadvantage of the process is spattering during melting of the electrode metal and its transfer to the weld pool, which affect the productivity of the process, reducing it $[1,2]$. Authors of publications [3-6], devoted to the improvement of technological processes of shieldedgas arc welding, based on theoretical and practical searches, came to the conclusion that the elimination of drawbacks is possible through the implementation of the controlled transfer of molten electrode metal into the weld pool. The implementation of such a transfer and the control of the processes that take place in the arc gap to a large extent determine the conditions for the qualitative formation of the deposited metal, process stability, the amount of electrode metal losses and the manufacturability of the processes of arc welding in shielding gases [7-9]. At the present stage of development of welding technologies, controlled transfer of electrode metal is possible due to the pulsed nature of arc burning [10 - 13].

When pulsed-arc welding, one of the main methods for increasing the efficiency of the process is to limit the maximum value of the short circuit current by increasing the inductive resistance $\mathrm{L}$ in the welding circuit [14 16]. The parameters of the inductive resistance of the welding circuit determine the current growth rate $v_{\mathrm{c}}$ during short-circuit, on which depends $I_{\text {s.c. }}^{\max }$, the stability of the welding process and spatter of the electrode metal $[1,17,18]$. Under the stable behaviour of the pulse-arc welding process, we will consider such a process in which there is no violation of the welding arc burning. A sign of violation of the arc burning will be the transition of the power source to open-circuit voltage, which will be recorded by the information-measuring system when registering the instantaneous values of current and voltage on the arc.

\section{PURPOSE AND METHODS}

Based on the features of mechanized arc welding, the aim of the research was to determine the influence of the value of the welding current growth rate during a short circuit on the stability of the welding arc.

It should be noted that in a pulse power supply, there is a structurally absent inductor that regulates the value of $v_{c}$, and, accordingly, the maximum value of the short circuit current $I_{\text {s.c. }}^{\max }$. To control these parameters, it is provided that the so-called virtual inductance $L_{V}$ is numerically laid in the controller at the program level, which determines the reaction rate of the source to a change in current in the "source-arc" circuit.

In connection with this feature, before performing experimental studies, the relationships between $L_{V}$ and $v_{\mathrm{c}}$ were determined using a computerized information-measuring system (IMS) [19]. For this, the inverter [20] was connected to the ballast rheostat according to the circuit in Fig. 1. When the circuit breakers were closed at $50 \mathrm{~A}$, and then at $100 \mathrm{~A}$ at different $L_{V}$ values, the analogue-digital converter IMS recorded a current jump from 50 A to 150 A using a connected current transformer.

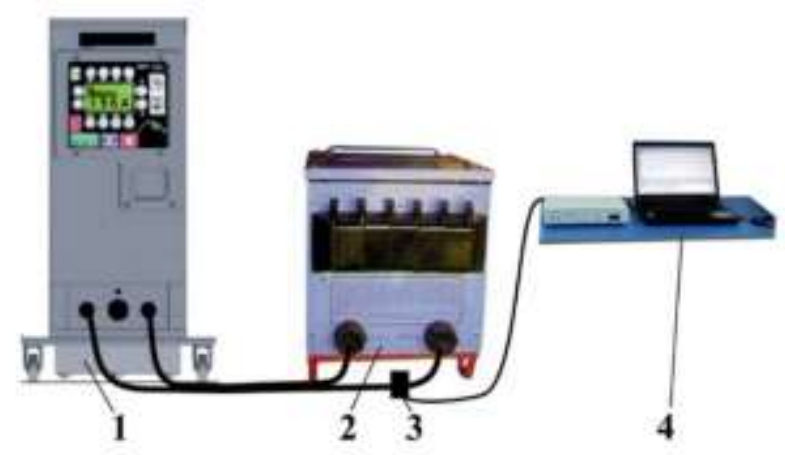

Fig. 1. Connection diagram of devices for determining the dependence of the value of $v_{\mathrm{c}}$ from the parameter $L_{V}: 1$ - power supply LET-500, 2 - ballast rheostat, 3 - current transformer, 4 - information-measuring system IMS 2007 
During operation, the IMS recorded the instantaneous values of the current flowing in the inverter-rheostat circuit, after which the time interval at which the current increased from 50 to $150 \mathrm{~A}$ was determined from the oscillogram (Fig. 2).

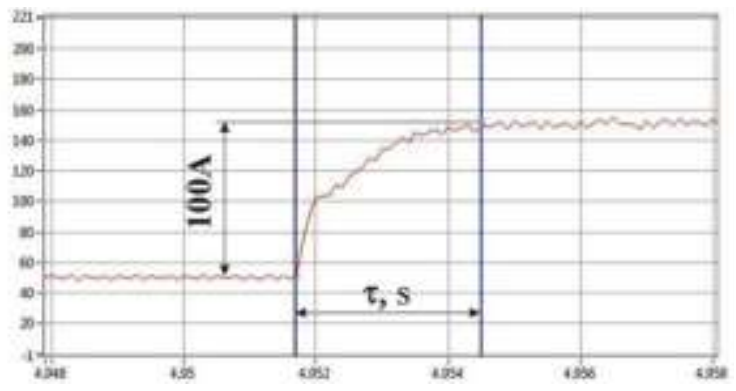

Fig. 2. An example of current oscillograms for determining the current growth rate from 50 to 150 A. $\tau$ is the current growth time by $100 \mathrm{~A}$

The value of $v_{\mathrm{c}}$ calculated according to a simple formula: $v_{\mathrm{c}}=100$ [A] $/ \tau$ [s]. Depending on the value of $L_{V}, \tau$ changed. The calculation results of $v_{\mathrm{c}}$ for different values of $L_{V}$ are shown in Table 1.

Table 1. The calculated values of $v_{\mathrm{c}}$ for different values of the parameter $L_{V}$

\begin{tabular}{|c|c|c|c|}
\hline $\begin{array}{c}L_{V}, \text { conven- } \\
\text { tional units }\end{array}$ & $v_{\mathrm{c}}, \mathrm{kA} / \mathrm{s}$ & $\begin{array}{c}L_{V}, \text { conven- } \\
\text { tional units }\end{array}$ & $v_{\mathrm{c}}, \mathrm{kA} / \mathrm{s}$ \\
\hline 9 & 50,0 & 21 & 1,23 \\
\hline 12 & 35,7 & 24 & 0,35 \\
\hline 15 & 11,4 & 27 & 0,22 \\
\hline 18 & 4,15 & 30 & 0,06 \\
\hline
\end{tabular}

The implementation of the experimental work involved surfacing on a plate with programming the inverter operation mode at different values of $L_{V}=9,12,15,18,21,24,27$, 30 . For this purpose, current-voltage characteristics (CVC) No.1 and No.2 were placed in the inverter (Fig. 3) and set the pulse mode with a frequency of $f=25 \mathrm{~Hz}$ and a duty cycle of $\mathrm{C}=$ 2.

Plate material - steel of strength class X70, wire - Sv08G2S with a diameter of $1.2 \mathrm{~mm}$, wire feed speed $V_{W}=5.1 \mathrm{~m} / \mathrm{min}$., shielding gas - $\mathrm{Ar}+\mathrm{CO}_{2}$, welding speed $V=30 \mathrm{~cm} / \mathrm{min}$.

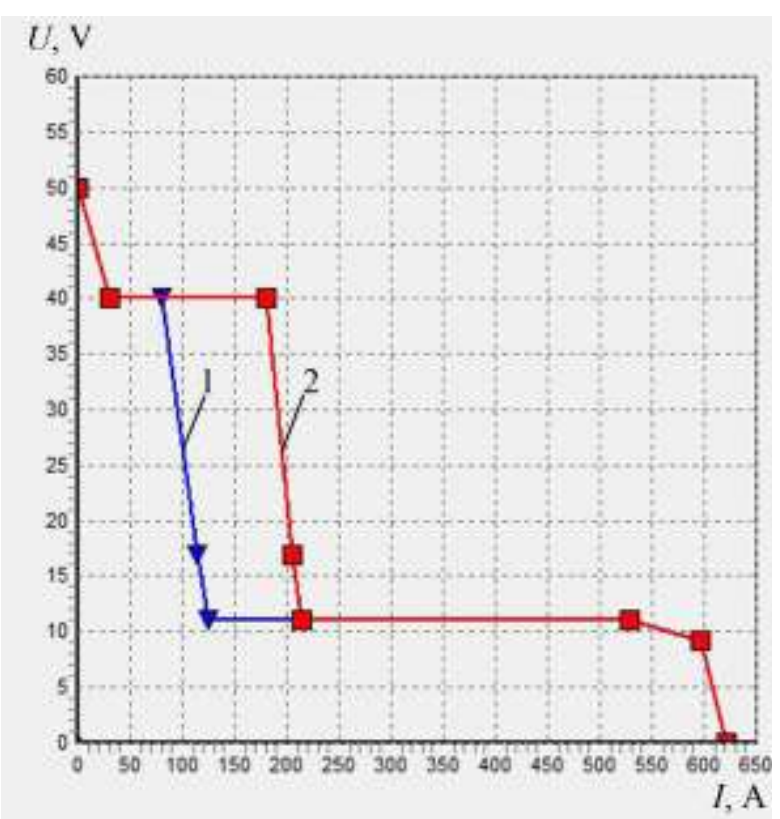

Fig. 3. CVC of a pulsed process with a frequency $f=25 \mathrm{~Hz}$ to determine the effect of the growth rate of the welding current $v_{\mathrm{c}}$ arc stability: 1,2 - inverter operation according to $I-V$ characteristics No. 1 and $I-V$ characteristics No.2, respectively

The heat input Q for each experiment was calculated using the well-known formula in which the values of $I_{A V}$ and $U_{A V}$ were determined by statistical processing of instantaneous values of current and voltage by the information-measuring system IMS 2007:

$$
Q=\frac{60 \cdot I_{\mathrm{av}} \cdot U_{\mathrm{av}}}{V} \cdot \eta,
$$

where $V$-welding speed ( $\mathrm{cm} / \mathrm{min}.), \eta=0.7$.

\section{RESULTS AND EXPLANATIONS}

The results of the analysis of the data recorded by the computerized IMS, and conclusions regarding the stability of the pulse process are shown in Table 2.

Evaluation of all recorded oscillograms of the arc voltage and their statistical processing shows that the value of $L_{V}$ significantly affects the stability of the pulse process during the transfer of metal with short circuits (Fig. 4). 
Table 2. Modes of the pulse-arc process at different values of $L_{V}$

\begin{tabular}{|c|c|c|c|c|c|c|l|}
\hline $\mathrm{N}$ & $L_{V}$ & $v_{\mathrm{c}}, \mathrm{kA} / \mathrm{s}$ & $I_{A V}, \mathrm{~A}$ & $U_{A V}, \mathrm{~V}$ & $Q, \mathrm{~kJ} / \mathrm{sm}$ & $I_{\text {s.c. }}^{\max }, \mathrm{A}$ & \multicolumn{1}{|c|}{ Note } \\
\hline 1 & 9 & 50,0 & 161 & 23,1 & 5,207 & 467 & Arc interruption \\
\hline 2 & 12 & 35,7 & 169 & 22 & 5,205 & 467 & Arc interruption \\
\hline 3 & 15 & 11,4 & 167 & 22,9 & 5,354 & $460-467$ & Arc interruption \\
\hline 4 & 18 & 4,15 & 172 & 22,25 & 5,358 & $430-435$ & $\begin{array}{l}\text { Reduction of the } \\
\text { arc interruption }\end{array}$ \\
\hline 5 & 21 & 1,23 & 172 & 21,8 & 5,249 & $350-360$ & $\begin{array}{l}\text { Reduction of the } \\
\text { arc interruption }\end{array}$ \\
\hline 6 & 24 & 0,35 & 173,5 & 21,8 & 5,295 & $330-350$ & $\begin{array}{l}\text { No arc interrup- } \\
\text { tion }\end{array}$ \\
\hline 7 & 27 & 0,22 & 175,1 & 21,56 & 5,285 & $\begin{array}{l}200-270 / \\
270-330\end{array}$ & $\begin{array}{l}\text { No arc interrup- } \\
\text { tion }\end{array}$ \\
\hline 8 & 30 & 0,06 & 172,1 & 21,94 & 5,286 & $\begin{array}{l}200-260 / \\
270-330\end{array}$ & $\begin{array}{l}\text { No arc interrup- } \\
\text { tion }\end{array}$ \\
\hline
\end{tabular}

So, at $L_{V}=9 \ldots 18$, which corresponds to the values of the welding current rise rate $v_{\mathrm{c}}=$ $50.0 \ldots 4.15 \mathrm{kA} / \mathrm{s}$, non-uniform breaks in the welding arc burning are observed. On oscillograms, this is reflected in the operation of the switching power supply at open-circuit voltage $U_{O C} \approx 60 \mathrm{~V}$ (Fig. 4, a-d). An increase in the value of $L_{V}$ to conventional values of 24...30, which due to the inverter control system significantly reduces the value of $v_{\mathrm{c}}$, Leads to the fact that the process of arc burning is much more stable, almost without breaks (Fig. 4, e-k). On the histogram, this is displayed by a sharp decrease in the number of instantaneous values of the power supply operation at $U_{O C}$.

When analysing the oscillograms of the welding current and the statistical processing of the $I-U$ characteristics of the process (Fig. 5 ), it was found that a decrease in the value of $v_{\mathrm{c}}$ leads to a significant limitation of the maximum value of the short circuit current. So, for example, at $v_{\mathrm{c}}=35.7 \mathrm{kA} / \mathrm{s}$ (Fig.5, a), there is, in addition to the already identified violations in the stability of continuous arc burning $\left(I_{W}=\right.$ $\left.0, U_{A}=U_{O C}\right)$, a wide range of the spread of the
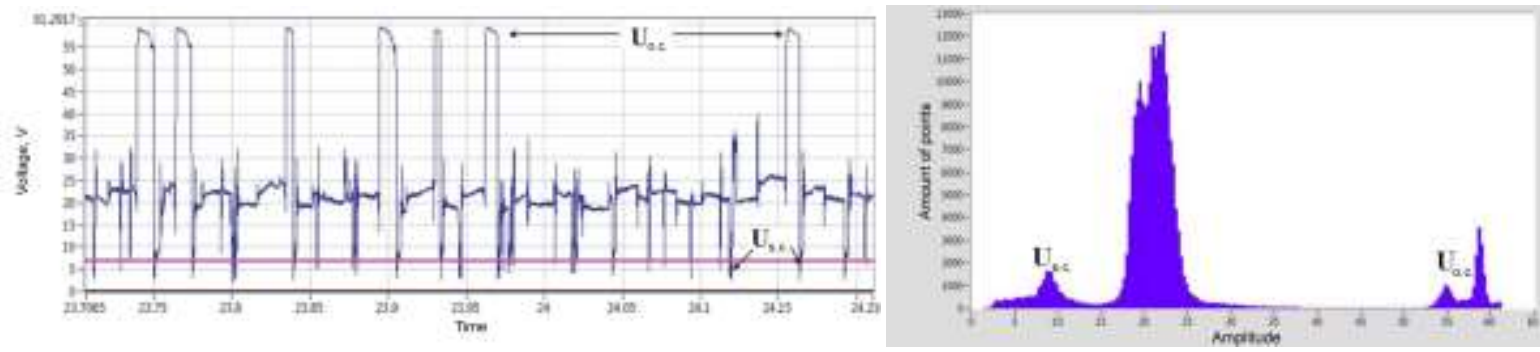

a
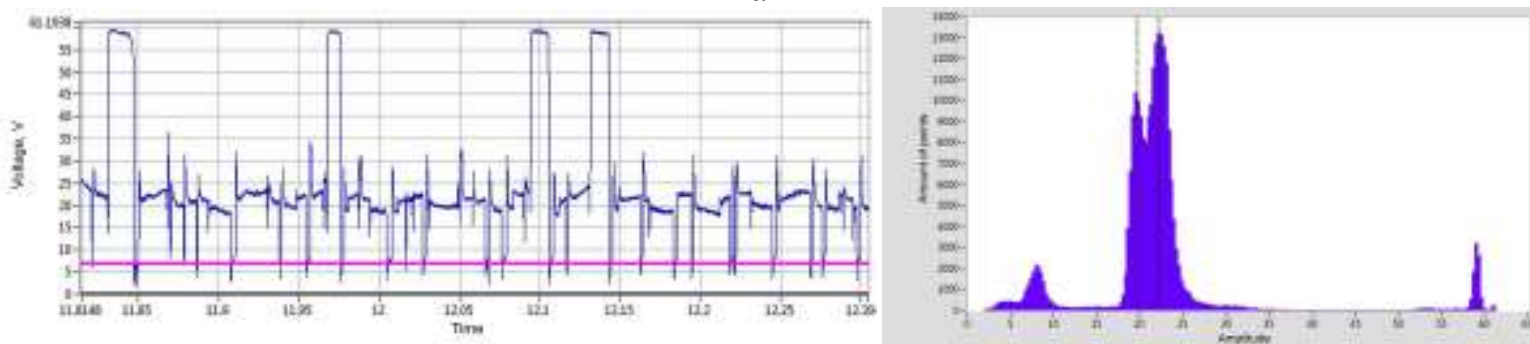

b

Fig. 4 (beginning). Oscillograms and histograms of the arc voltage at different $L_{V}$ values: a $-9\left(v_{\mathrm{c}}=50\right.$ $\mathrm{kA} / \mathrm{s}) ; \mathrm{b}-12\left(v_{\mathrm{c}}=37.5 \mathrm{kA} / \mathrm{s}\right) ; \mathrm{c}-15\left(v_{\mathrm{c}}=11.4 \mathrm{kA} / \mathrm{s}\right) ; \mathrm{d}-18\left(v_{\mathrm{c}}=4.15 \mathrm{kA} / \mathrm{s}\right) ; \mathrm{e}-21\left(v_{\mathrm{c}}=1.23\right.$ $\mathrm{kA} / \mathrm{s}) ; \mathrm{f}-24\left(\nu_{\mathrm{c}}=0.35 \mathrm{kA} / \mathrm{s}\right) ; \mathrm{g}-27\left(\nu_{\mathrm{c}}=0.22 \mathrm{kA} / \mathrm{s}\right) ; \mathrm{h}-30\left(\nu_{\mathrm{c}}=0.06 \mathrm{kA} / \mathrm{s}\right) . U_{S C}-$ instantaneous voltage values during short circuit, $U_{O C}$ - instantaneous voltage values when the power source is working at open circuit voltage 

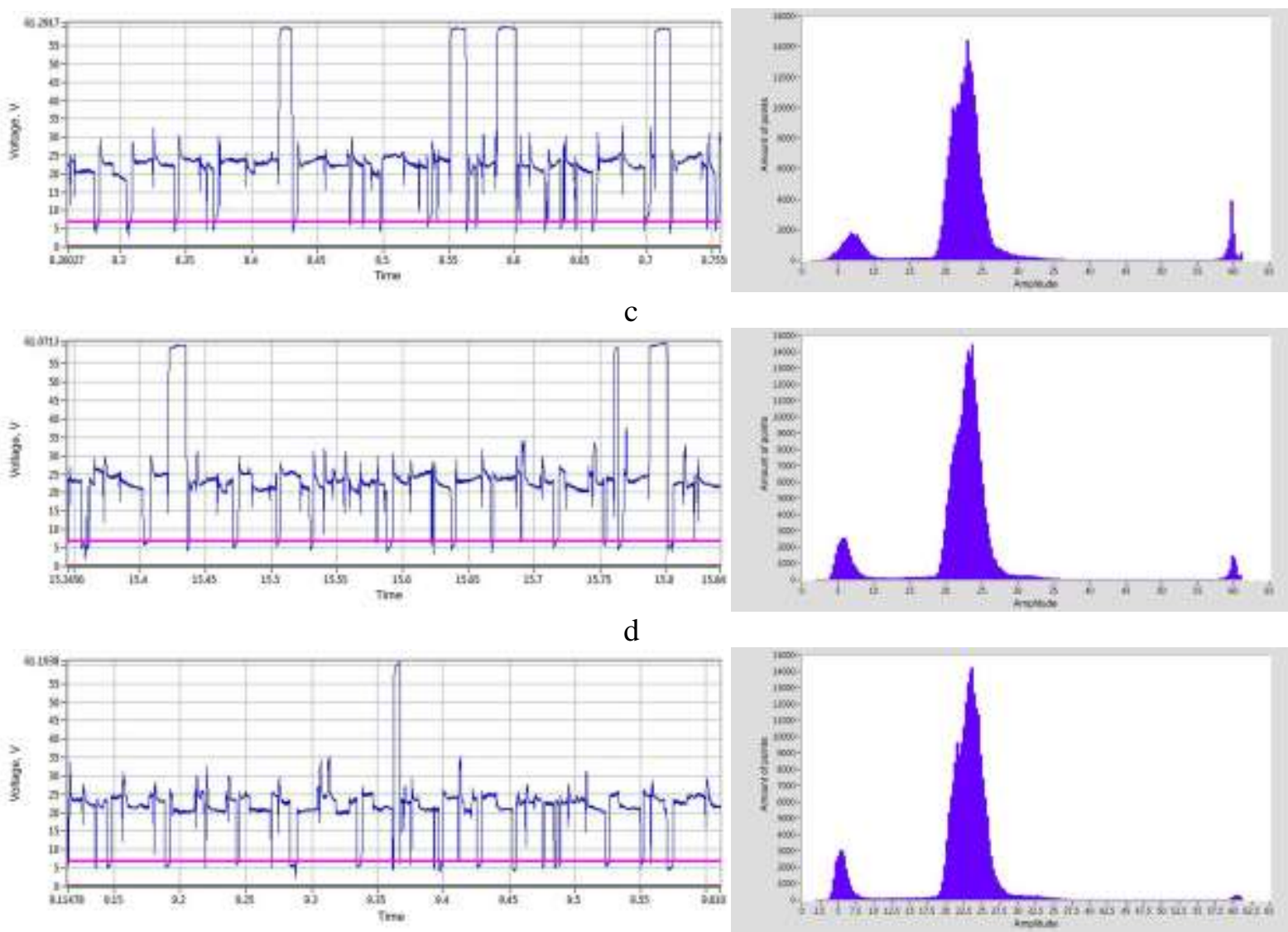

$\mathrm{e}$
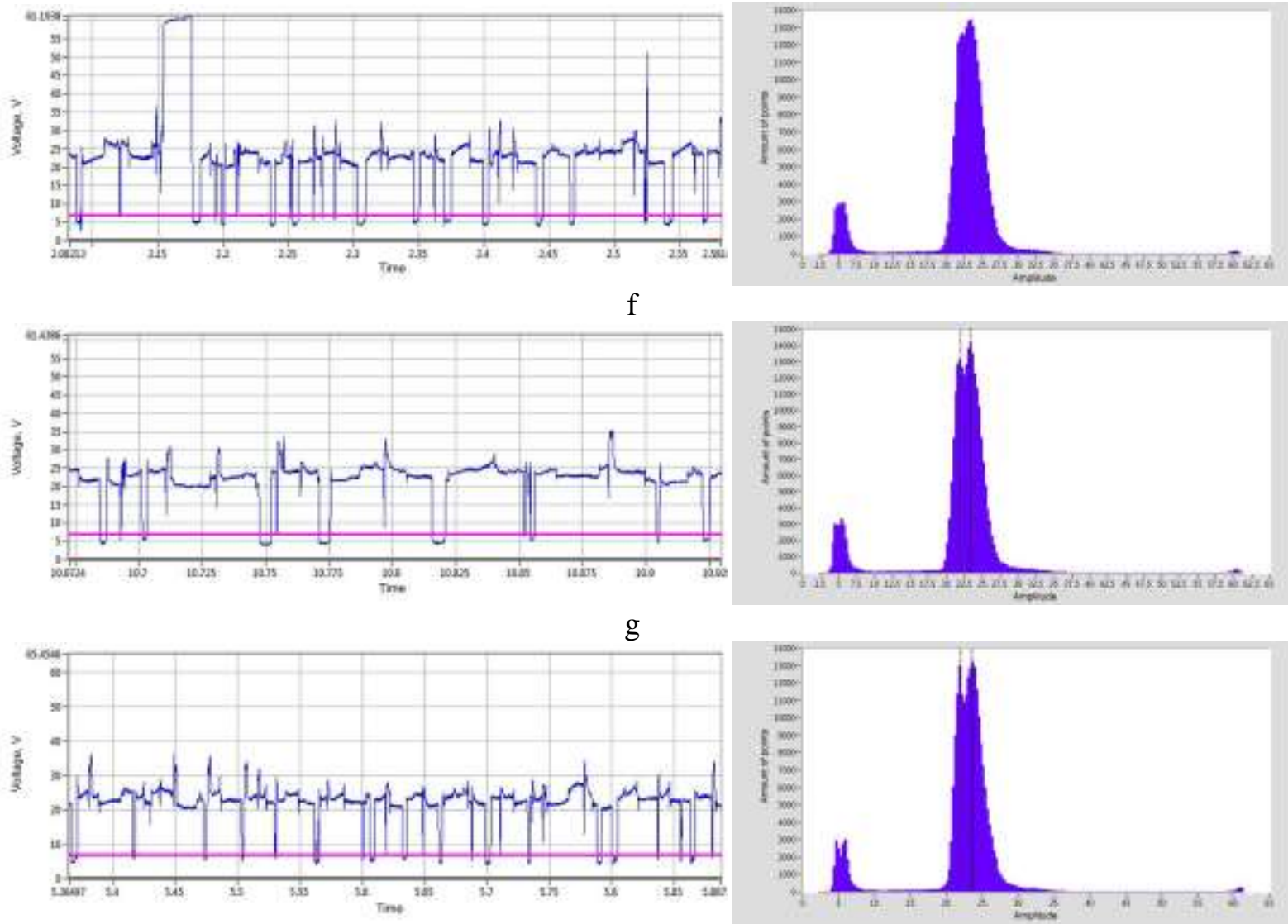

$\mathrm{h}$

Fig. 4 (the end). Oscillograms and histograms of the arc voltage at different $L_{V}$ values 
instantaneous values $I_{S C}=120 \ldots 465$ A zone. The maximum value of the short circuit current in many cases was $I_{\text {s.c. }}^{\max }=467 \mathrm{~A}$. When surfacing, this was reflected in a high sputtering of molten metal.

A gradual increase in virtual inductance to $L_{V}=24 \ldots 30\left(v_{\mathrm{c}}=0.35 \ldots 0.06 \mathrm{kA} / \mathrm{s}\right)$ led to a significant change in the quality of the pulse process (Fig. 5, f-h). The maximum short circuit current decreased by 130 A to $I_{\text {s.c. }}^{\max }=$ $330 \ldots 350 \mathrm{~A}$ and the zone of dispersion of instantaneous values was $I_{S C}=200 \ldots 330 \mathrm{~A}$.

The entire zone of instantaneous values $I_{S C}$ is divided into two ranges: the first $-200 . . .260$ $\mathrm{A}$ and the second $270 \ldots 350 \mathrm{~A}$. It can be assumed that the first range corresponds to a short circuit at the time of operation of the
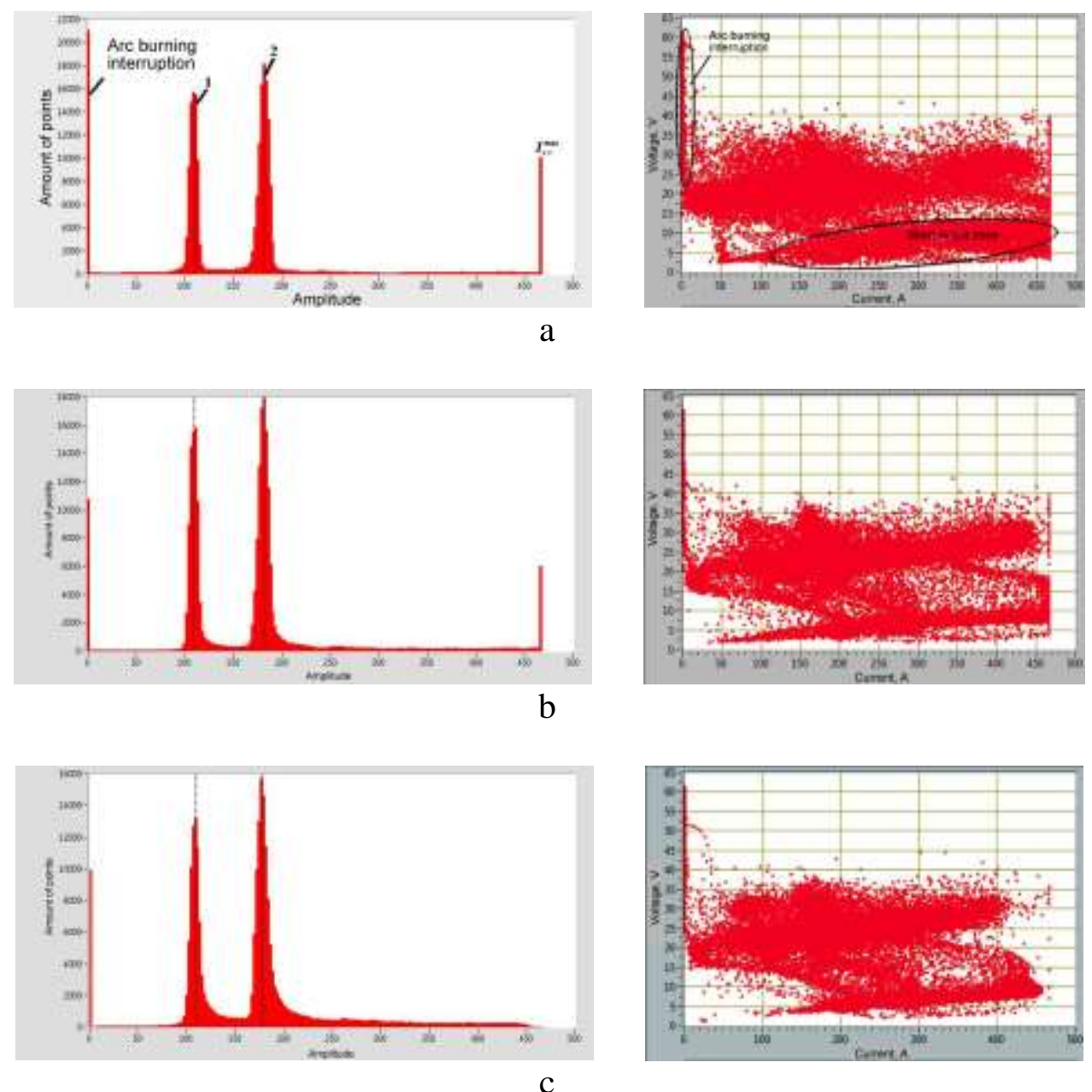

Fig. 5 (beginning). Histograms of the welding current and the current-voltage characteristic of a pulsed process with short circuits at different $L_{V}$ values: a $-9\left(v_{\mathrm{c}}=50 \mathrm{kA} / \mathrm{s}\right) ; \mathrm{b}-12\left(v_{\mathrm{c}}=\right.$ $37.5 \mathrm{kA} / \mathrm{s}) ; \mathrm{c}-15\left(v_{\mathrm{c}}=11.4 \mathrm{kA} / \mathrm{s}\right) ; \mathrm{d}-18\left(v_{\mathrm{c}}=4.15 \mathrm{kA} / \mathrm{s}\right) ; \mathrm{e}-21\left(v_{\mathrm{c}}=1.23 \mathrm{kA} / \mathrm{s}\right) ; \mathrm{f}-24$ $\left(v_{\mathrm{c}}=0.35 \mathrm{kA} / \mathrm{s}\right) ; \mathrm{g}-27\left(v_{\mathrm{c}}=0.22 \mathrm{kA} / \mathrm{s}\right) ; \mathrm{h}-30\left(v_{\mathrm{c}}=0.06 \mathrm{kA} / \mathrm{s}\right) .1,2-$ inverter operation according to $I-V$ characteristics No.1 and No.2, respectively 

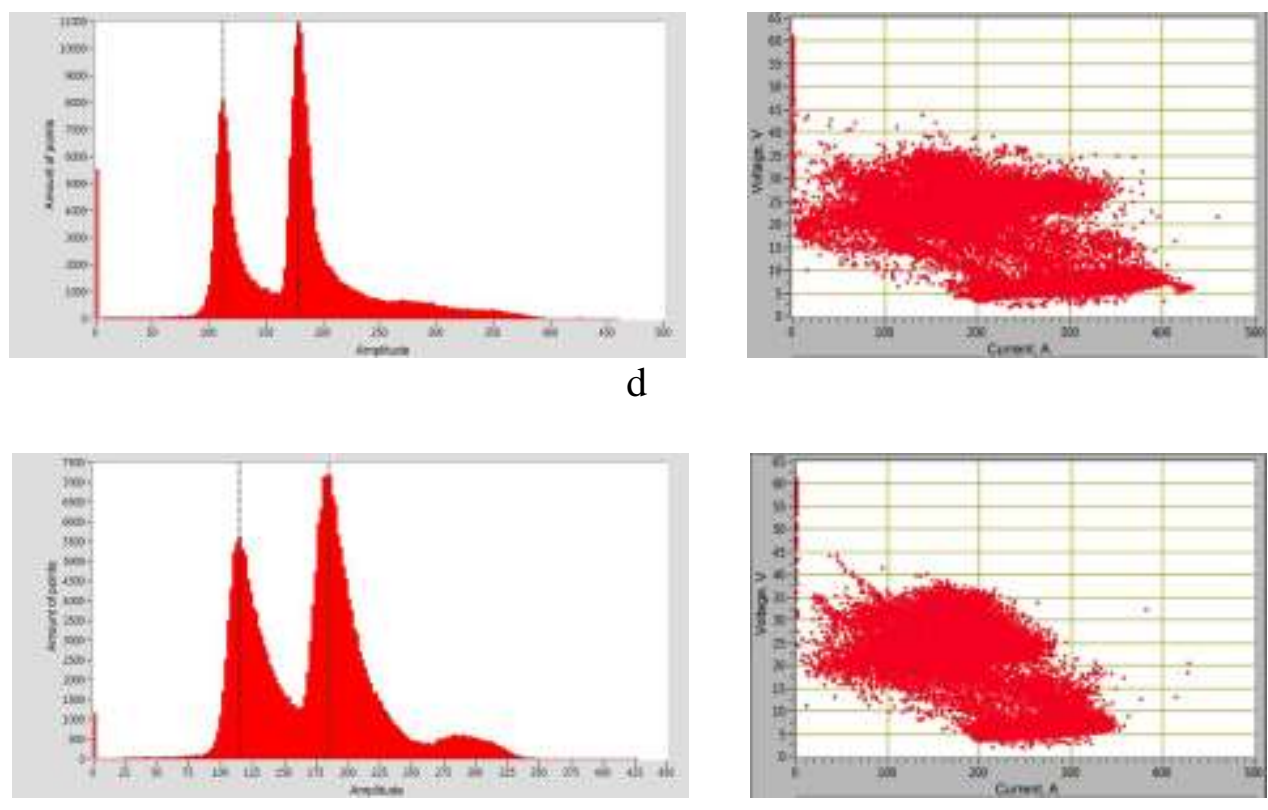

$\mathrm{e}$
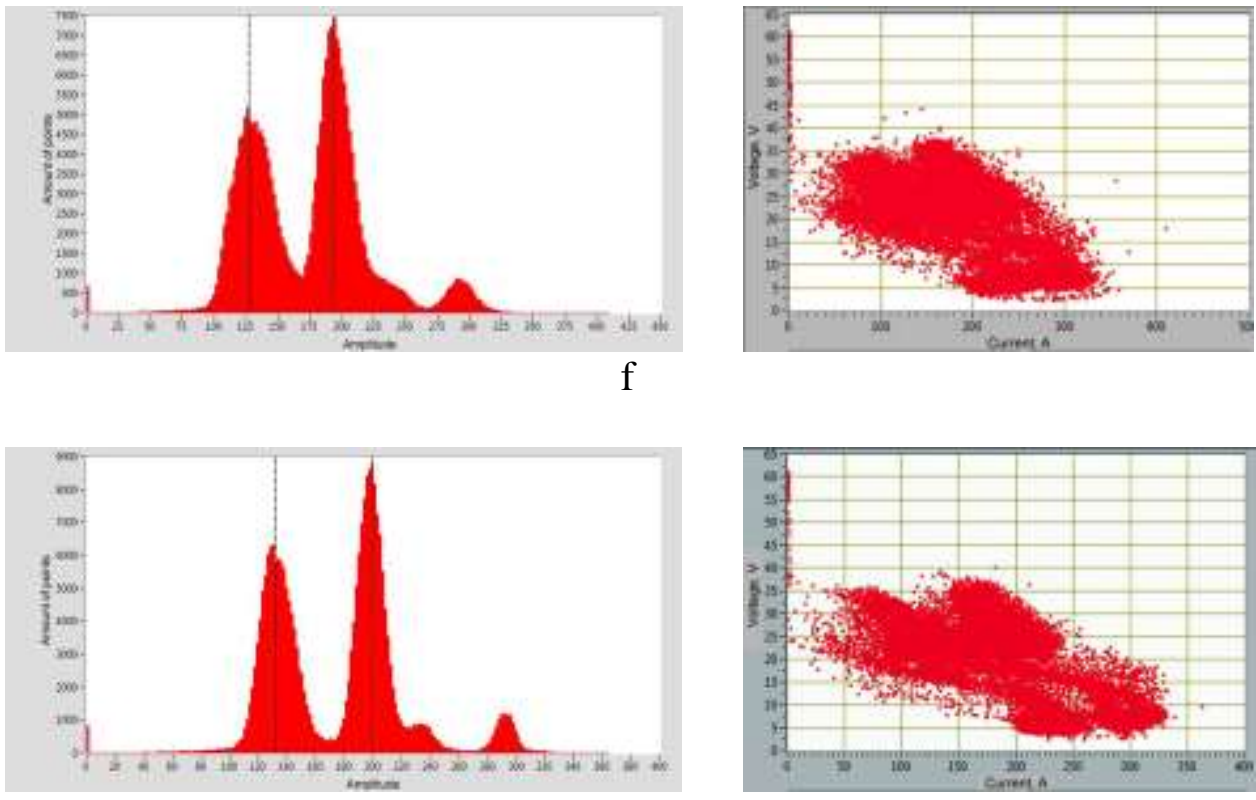

$\mathrm{g}$
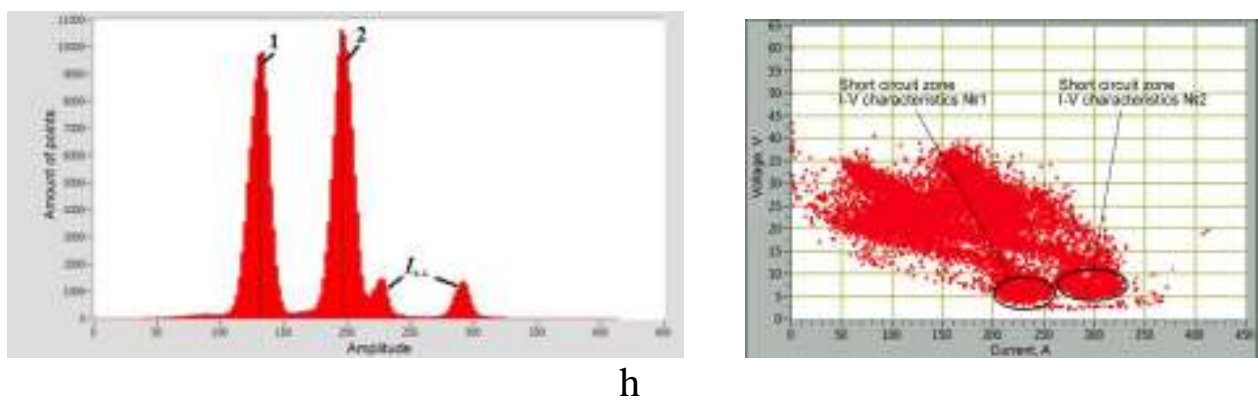

Fig. 5 (the end). Histograms of the welding current and the current-voltage characteristic of a pulsed process with short circuits at different $L_{V}$ values 


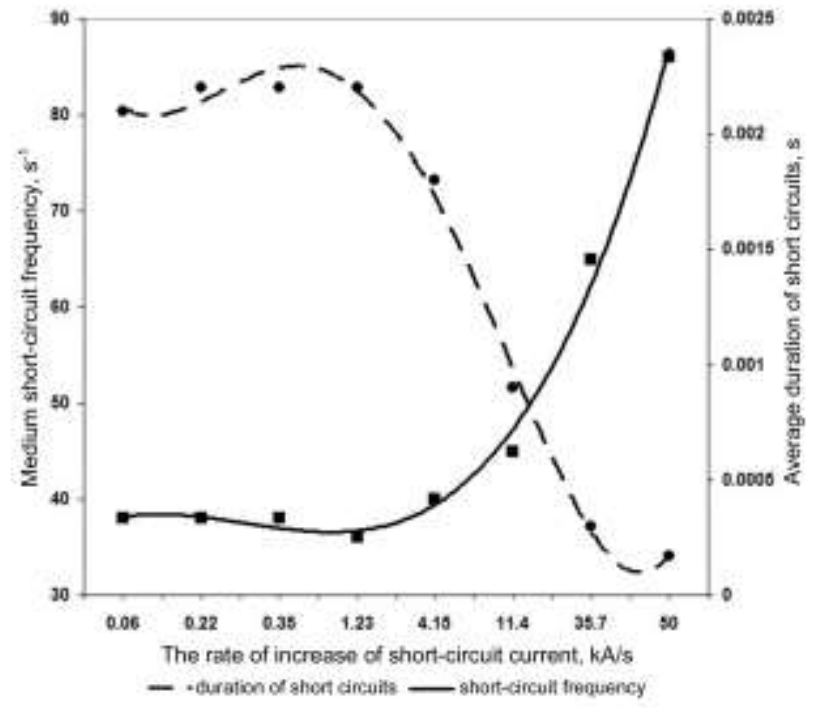

a

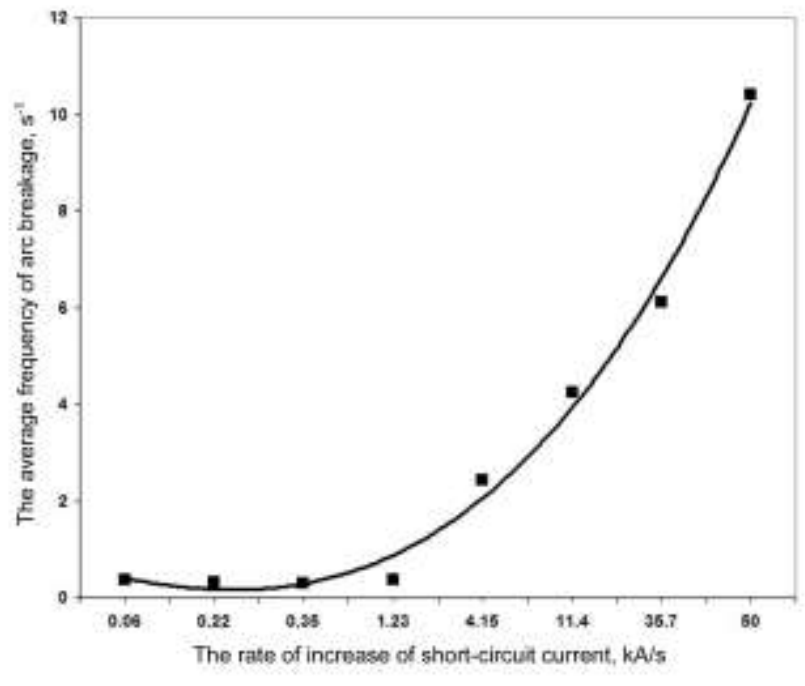

$\mathrm{b}$

Fig. 6. The influence of the short-circuit current growth rate on: a - the average frequency and duration of short-circuit; $b$ - the stability of the pulse-arc welding process

change significantly since the values of $I_{A V}$ and $U_{A V}$ remained at the same level $(160 \ldots 170 \mathrm{~A}$, $21 \ldots 22.5 \mathrm{~V})$, the heat input $Q$ was in the range of $5.20 \ldots . .35 \mathrm{~kJ} / \mathrm{cm}$.

Statistical analysis also confirmed the conclusion (Fig. 6, b) that the increase in $v_{\mathrm{c}}$ leads to a violation of the stability of the pulse process and this is reflected in an increase in the average frequency of arc breakage by more than 30 times from $0.33 \mathrm{~s}^{-1}$ (for $v_{\mathrm{c}}=$ $0.06 \ldots 1.23 \mathrm{kA} / \mathrm{s}$ ) to $10 \mathrm{~s}^{-1}$ (for $v_{\mathrm{c}}=50 \mathrm{kA} / \mathrm{s}$ ).

To determine how the growth of the welding current $v_{\mathrm{c}}$ affects the stability of the pulsed process if it is necessary to increase the heat input $Q$, additional experimental and theoretical studies were carried out. To do this, the $I-$ $V$ characteristic was placed in the inverter (Fig. 7 ), in which the falling sections of the $I-V$ characteristics No.1 and No.2 (in the range of $40-11 \mathrm{~V}$ ) were shifted in the direction of increasing the welding current by $100 \mathrm{~A}$ compared to the previous version programming the power source (see Fig. 3). The pulse process was carried out with a frequency $f=25 \mathrm{~Hz}$, the welding speed $V=30 \mathrm{~cm} / \mathrm{min}$., the wire feed speed $V_{W}=7.7 \mathrm{~m} / \mathrm{h}$, the shielding gas $-\mathrm{Ar}+$ $\mathrm{CO}_{2}$.

The results of processing these data by a computerized information-measuring system are shown in Table 3.
An analysis of the obtained data and their comparison with the results of previous experiments (Fig. 6, a) showed that an increase

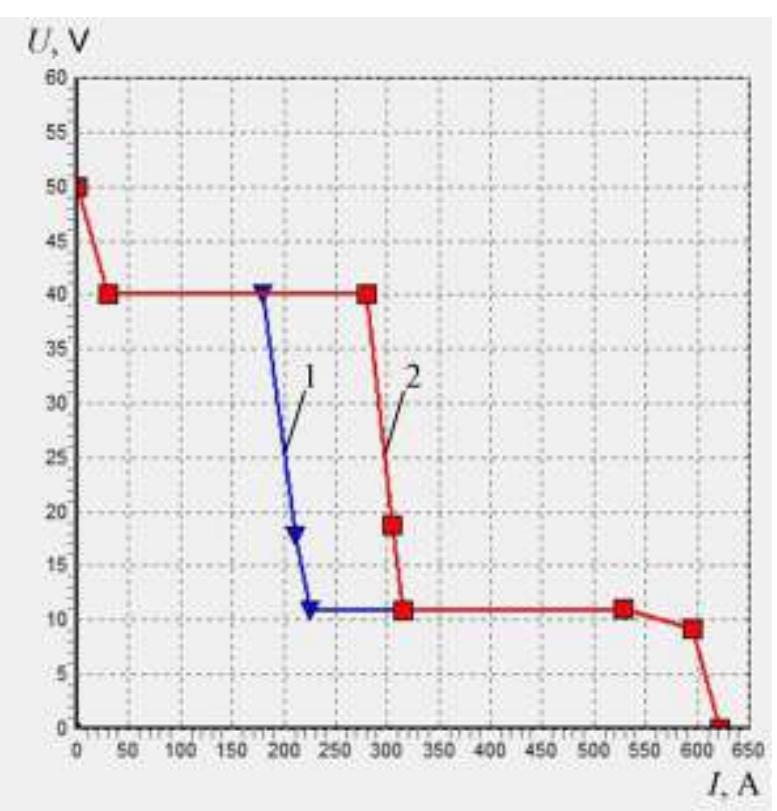

Fig. 7. Current-voltage characteristics of the pulse process to determine the effect of the growth rate of the welding current $v_{\mathrm{c}}$ on the stability of arc burning at heat input $Q=$ $7.8 \ldots 8.0 \mathrm{~kJ} / \mathrm{cm} .1,2$ - inverter operation according to $I-V$ characteristics No.1 and No.2, respectively 
Table 3. Welding modes and data processing results

\begin{tabular}{|c|c|c|c|c|c|c|c|c|c|}
\hline $\mathrm{N}$ & $L_{V}$ & $v_{\mathrm{c}}, \mathrm{kA} / \mathrm{s}$ & $\begin{array}{c}I_{\mathrm{AW}}, \\
\mathrm{A}\end{array}$ & $U_{\mathrm{AW}}, \mathrm{V}$ & $\underset{\mathrm{kJ} / \mathrm{sm}}{Q,}$ & $\begin{array}{c}I_{\text {s.c. }}^{\max } \\
\text { A }\end{array}$ & $\begin{array}{c}\text { Average fre- } \\
\text { quency of short } \\
\text { circuits, } \mathrm{s}^{-1} \\
\end{array}$ & $\begin{array}{l}\text { Short circuit } \\
\text { average dura- } \\
\text { tion, s }\end{array}$ & Note \\
\hline 1 & 9 & 50,0 & 220 & 25,8 & 7,946 & 467 & 27 & 0,00021 & \multirow{8}{*}{ 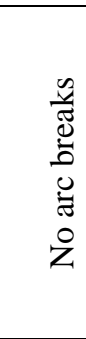 } \\
\hline 2 & 12 & 35,7 & 220 & 25,9 & 7,977 & 467 & 26 & 0,00050 & \\
\hline 3 & 15 & 11,4 & 225 & 24,5 & 7,717 & 450 & 25 & 0,00080 & \\
\hline 4 & 18 & 4,15 & 223 & 25,4 & 7,930 & 410 & 22 & 0,00089 & \\
\hline 5 & 21 & 1,23 & 223 & 25,5 & 7,961 & 390 & 20 & 0,00090 & \\
\hline 6 & 24 & 0,35 & 222 & 25,9 & 8,050 & 385 & 17 & 0,00096 & \\
\hline 7 & 27 & 0,22 & 225 & 25,0 & 7,875 & 385 & 21 & 0,00098 & \\
\hline 8 & 30 & 0,06 & 225 & 24,9 & 7,843 & 385 & 22 & 0,00094 & \\
\hline
\end{tabular}

in the energy parameters of the pulsed-arc welding to the level of $I_{E W}=220 \ldots .225 \mathrm{~A}, U_{E W}$ $=24.5 \ldots 25.9 \mathrm{~V}, Q \approx 7.9 \ldots 8.0 \mathrm{~kJ} / \mathrm{cm}$ led to changes in the parameters that characterize the process of pulse welding with short circuits. A sharp decrease in the average frequency of short circuits (2...3 times) and their average duration (2 times) took place. The reason for this should be considered that the increase in energy indicators changed the type of transfer of liquid metal - the welding process with short circuits (Fig. 8a) turned into a mixed process [15], in which, along with short circuits, a droplet transfer of electrode metal is observed (Fig. 8b). In the latter case, part of the molten metal flows into the weld pool in small drops, while the short circuit time is much shorter (3...5 times) than with a conventional short circuit. As a result of this, the arc voltage remains at the level of $U_{S C}>$ $12 \ldots 15 \mathrm{~V}$ and does not have time to decline to the accepted values of $U_{S C}=5 \ldots 10 \mathrm{~V}$.

Since the IMS 2007 statistically calculates the cases of short circuit for the condition $U_{S C}$ $=5 \ldots 10 \mathrm{~V}$ and does not take into account larger voltage values, the calculated average frequency of short circuits is lower.

Processing oscillograms of the welding current and voltage showed that pulse-arc welding proceeds stably without disturbances in the welding arc burning in the entire range of the control value $L_{V}=9 \ldots 30\left(v_{\mathrm{c}}=50.0 \ldots 0.06\right.$ $\mathrm{kA} / \mathrm{s}$ ).

\section{CONCLUSIONS}

1. The increase in the inductance of the power source, which due to the control system of the inverter significantly reduces the slew rate of the short circuit current, leads to stabilization of the pulse-arc welding process with short circuits.

2. An increase in the growth rate of the short circuit current $v_{\mathrm{c}}$, starting from $1.23 \mathrm{kA} / \mathrm{s}$ to $50 \mathrm{kA} / \mathrm{s}$, leads to a decrease in the average duration of the short circuit by at least 10 times. At the same time, the average frequency of short circuits increases more than 2 times.

3. An increase in the energy indices of pulse-arc welding led to a sharp decrease in the average frequency of short circuits $(2 \ldots 3$ times) and their average duration (2 times). As a result, the process proceeds stably without disturbances in the burning of the welding arc in the entire range of changes in the inductance of the power source.

\section{REFERENCES}

1. Potap'yevskiy A.G., Sarayev Yu.N., Chinakhov D.A., 2012. Svarka staley v zashchitnykh gazakh plavyashchimsya elektrodom. Tekhnika i tekhnologiya budushchego. Tomsk, 208 (in Russian).

2. Sarayev Yu.N., Lunov A.G., Semenchuk V.M. etc., 2019. Kineticheskiye osobennosti teplomassoperenosa v usloviyakh svarki i naplavki. Izvestiya vysshikh uchebnyy zavedeniy. Fizika, Vol.62, 34-40 (in Russian).

3. Paton B.Ye., Dudko D.A., Sidoruk B.C., 1988. Sostoyaniye i perspektivy razvitiya elektricheskoy svarki plavleniyem s modulyatsiyey parametrov rezhima. Impul'snye protsessy svarki: Sb. nauch. Tr. Kiyv, IES im. E.O.Patona, 5-11 (in Russian). 


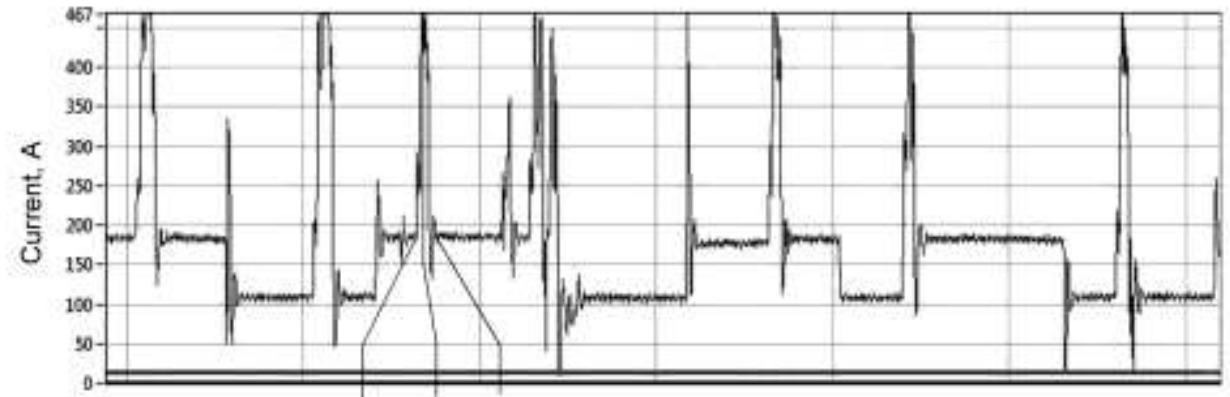

$144_{\text {somatan }}$

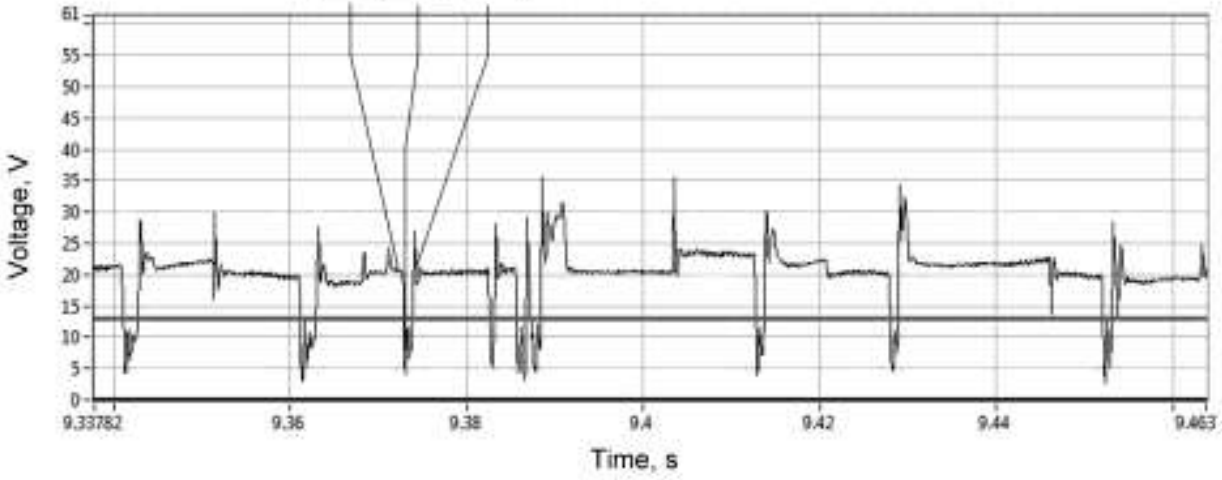

a)
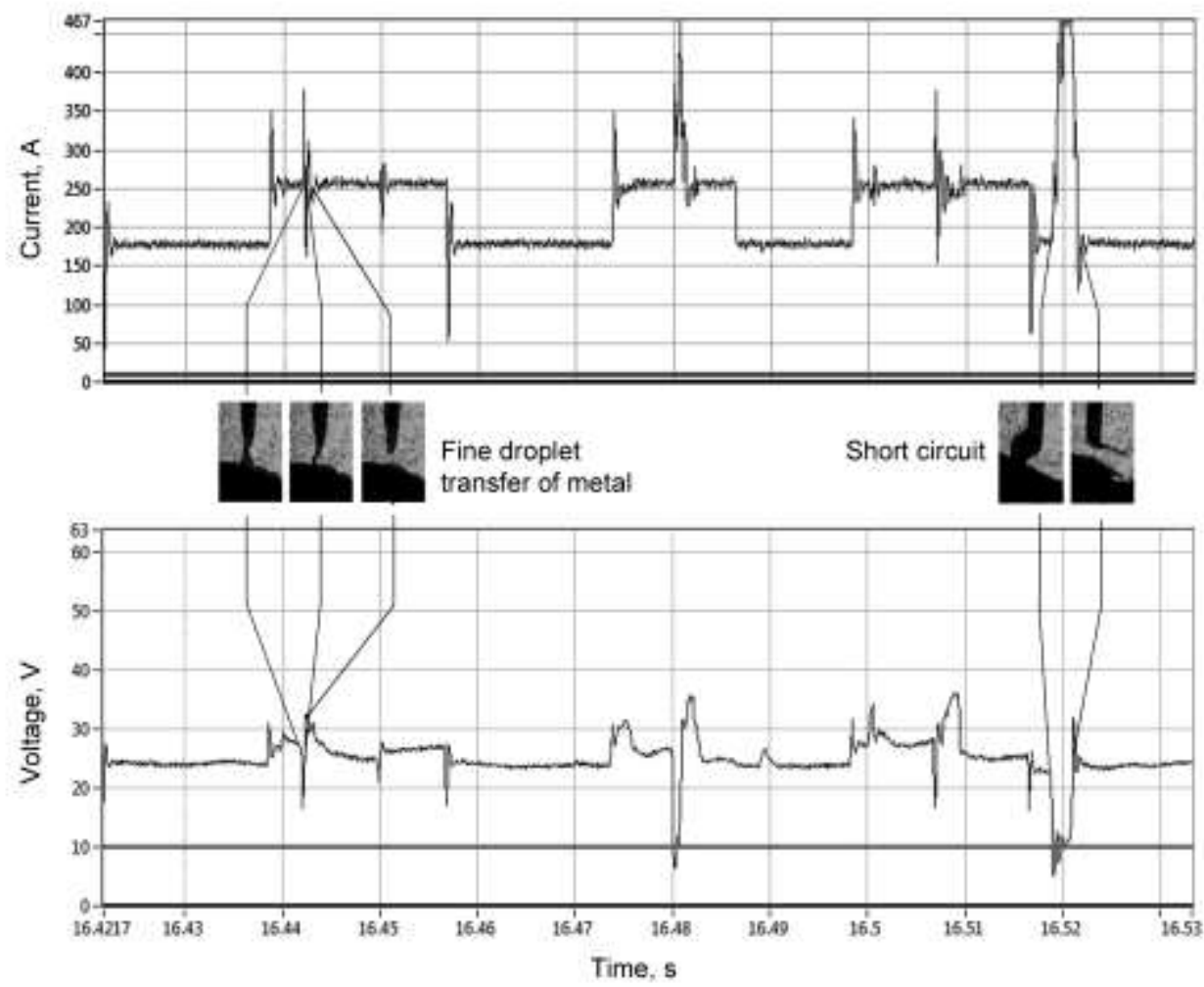

b)

Fig. 8. Oscillograms of current and voltage of the pulse process at $v_{\mathrm{c}}=50 \mathrm{kA} / \mathrm{s}$ : a - process with short circuit $(Q=5.207 \mathrm{~kJ} / \mathrm{cm}) ; \mathrm{b}-$ mixed process $(Q=7.946 \mathrm{~kJ} / \mathrm{s})$ 
4. Chao Chen, Sanbao Lin, Chenglei Fan etc., 2018. Feasibility analysis of pulsed ultrasonic for controlling the GMAW process and weld appearance. The International Journal of Advanced Manufacturing Technology, Vol.97, 3619-3624.

5. Kaiyuan Wu, Tong Yin, Nian Ding etc., 2018. Effect of phase on the behavior of metal transfer in double-wire pulsed GMAW. The International Journal of Advanced Manufacturing Technology, V.93, 3777-3789.

6. Zhang Shuai, Cheng Fangjie, Di Xinjie etc., 2016. Study on arc characteristics and behavior of metal transfer in pulse current flux-cored arc welding of mild steel. China Welding, No.4, 42-51.

7. Mezrag B., Deschaux-Beaume F., Benachour M., 2015. Control of mass and heat transfer for steel/aluminium joining using Cold Metal Transfer process. Science and Technology of Welding and Joining, Vol.20, 189-198.

8. Lebedev Vladimir, Reisgen Uwe, Lendiel Ivan, 2016. Study of technological opportunities of GMA welding and surfacing with pulse electrode wire feed. Welding in the World, Vol.60, 525-533.

9. Panga Jie, Hua Shengsun, Shena Junqi etc., 2016. Arc characteristics and metal transfer behavior of CMT $+\mathrm{P}$ welding process. Journal of Materials Processing Technology, Vol. 238, 212-217.

10. Kamal Pal, Surjya K. Pal, 2011. Effect of Pulse Parameters on Weld Quality in Pulsed Gas Metal Arc Welding: A Review. Journal of Materials Engineering and Performance, Vol.20, 918-931.

11. Praveen P., Yarlagadda P., Kangb M.J., 2005. Advancements in pulse gas metal arc welding. Journal of Materials Processing Technology, Vol.164-165, 1113-1119.

12. DeRuntz, B.D., 2001. Surface Tension Transfer welding in manufacturing. Selected Paper presented at the National Association of Industrial Technology Conference, Detroit Michigan, 20-26.

13. Dos Santos Emanuel B. F., Pistor Rob, Gerlich Adrian P., 2017. Pulse profile and metal transfer in pulsed gas metal arc welding droplet formation, detachment and velocity. Science and Technology of Welding and Joining, Vol.22, 627-641.

14. Agrawal Banshi Prasad, Kumar Rajeev, 2016. Challenges in Application of Pulse Current Gas Metal Arc Welding Process for Preparation of Weld Joint with Superior Quality. In- ternational Journal of Engineering Research \& Technology, Vol.5, 319-327.

15. Ghosh P.K., 2017. Concept of Pulse Current Gas Metal Arc Welding Process. Pulse Current Gas Metal Arc Welding: Characteristics, Control and Applications, 31-45.

16. Mainak Sen, Manidipto Mukherjee, Santosh Kumar Singh, 2018. Effect of doublepulsed gas metal arc welding (DP-GMAW) process variables on microstructural constituents and hardness of low carbon steel weld deposits. Journal of Manufacturing Processes, Vol.31, 424-439.

17. Saraev Y.N., Lunev A.G., Semenchuk V.M. etc., 2019. Enhancing an arc welding technology by the methods of adaptive pulsed control of energetic parameters. IOP Conf. Series: Materials Science and Engineering, Vol.681 (2019) doi:10.1088/1757-899X/681/1/012038.

18. Zhao Yangyang, Chung Hyun, 2018. Influence of power source dynamics on metal and heat transfer behaviors in pulsed gas metal arc welding. International Journal of Heat and Mass Transfer, Vol.121, 887-899.

19. Pirumov A.Ye., Skachkov I.O., Maksimov S.Yu. etc., 2007. Spetsializirovannaya informatsionno-izmeritel'naya sistema dlya monitoringa protsessa svarki. Avtomaticheskaya svarka, 8, 41-43 (in Russian).

20. Vladimirov A.V., Khabuzov V.A., Lebedev V.A. etc., 2011. Universal'nyy istochnik pitaniya dlya elektrodugovoy svarki i plazmennoy rezki na osnove tsifrovogo sinteza tekhnologicheskogo protsessa. Avtomaticheskaya svarka, 1, 41-46 (in Russian).

\section{Стабилизация процесса механизированной импульсно-дуговой сварки \\ Сергей Максимов, Анатолий Гаврилюк, Денис Кражановский}

Аннотация. Главным недостатком процесса механизированной дуговой сварки в защитных газах с короткими замыканиями является разбрызгивание при плавлении электродного металла и его переносе в сварочную ванну, что сказываются на производительности процесса, снижая ее. Его устранение возможно путём реализации управляемого переноса расплавленного электродного металла в сварочную ванну. Реализация такого переноса и контроль процессов, которые проходят при этом в дуго- 
вом промежутке, в значительной степени определяют условия качественного формирования наплавленного металла, стабильность процесса, величину потерь электродного металла и технологичность процессов дуговой сварки в защитных газах. На современном этапе развития сварочных технологий управляемый перенос электродного металла возможен за счет импульсного характера горения дуги. При этом одним из основных приёмов повышения эффективности процесса является ограничение максимальной величины тока короткого замыкания за счет увеличения индуктивного сопротивления в сварочной цепи.

Цель проведенных исследований - определение влияния величины скорости роста сварочного тока при к.з. на стабильность горения сварочной дуги. Установлено, что увеличение скорости роста тока, начиная с 1,23 кА/с до 50 кА/c, приводит к уменьшению средней продолжительности короткого замыкания не менее чем в 10 раз. Одновременно с этим увеличивается средняя частота коротких замыканий более чем в 2 раза, с $36 \ldots 38 \mathrm{c}^{-1}$ до $80 \ldots 86 \mathrm{c}^{-1}$. Причина этого заключается в росте значений электродинамической силы Лоренца, действие которой приводит к сжатию перемычки жидкого металла капли (пинч-эффект) вследствие увеличения величины тока короткого замыкания. При этом наблюдается нарушение стабильности импульсного процесса и это отражается в увеличении средней частоты обрывов дуги более чем в 30 раз с $0,33 \mathrm{c}^{-1}$ до $10 \mathrm{c}^{-1}$. Увеличение энергетических показателей процесса сварки привело к уменьшению средней частоты коротких замыканий (в 2 ... 3 раза) и средней продолжительности к.з. (в 2 раза). Причиной этого следует считать изменение типа переноса жидкого металла - процесс сварки с короткими замыканиями превратился в смешанный процесс, в котором наряду с короткими замыканиями наблюдается мелкокапельный перенос жидкого металла.

Ключевые слова: механизированная дуговая сварка, защитные газы, стабильность горения, сварочная дуга, управляемый перенос, источник тока, индуктивное сопротивление, скорость роста сварочного тока, короткое замыкание. 